\title{
Seismic Performance Comparison of a Building Made with Old Masonry Bayburt Stone According to Old and New TBDY.
}

\author{
Omer Can \\ Civil Engineering Department, Bayburt University \\ 21 Subat street Bayburt 69010, Turkey \\ E-mail: ocan@bayburt.edu.tr
}

\begin{abstract}
Turkey is home of a very rich geography and cultural heritage which is seen in the contemplation of its history. As in every society, efforts are being made to protect the existing cultural heritage in our country. It is our responsibility to protect, maintain and strengthen this heritage. Most of the buildings representing the richness of our culture are masonry structures. In the performance examination of these structures, there are difficulties in determining and interpreting their performances due to the properties' variabilities of materials used in their construction. In this study, a masonry building located in Bayburt a western city of Turkey built between 1941-1942 using Bayburt stone was examined, information about construction technique, soil properties and material properties as well as existing problems of the structure were compiled and observed. The values obtained as a result of a survey study performed on the structure were moved to AutoCAD program and modelled with StatiCAD-Masonry Program. It was aimed to compare the earthquake performance analysis of the structure according to Old Turkey Building Earthquake Regulation (TBDY-2007) and New Turkey Building Earthquake Regulation (TBDY-2018). In the light of the analyses, the structural performance of Bayburt stone was examined and analysed according to regulations.
\end{abstract}

Keywords: Performance Analysis, StatiCAD- Masonry, Masonry Building, Earthquake Regulation

DOI: $10.7176 / J S T R / 5-11-04$

\section{Introduction}

It is an undeniable fact that our country is highly prone to earthquakes. $93 \%$ of Turkey's territory is located in an earthquake zone. There have been 182 major earthquakes in Turkey since 1900 [1]. We must be aware of earthquakes in order to be prepared to survive one. Among the major reasons for buildings to be non-earthquake resistant are, the non-usage of known earthquake resistant engineering techniques in buildings, the non-application of any building control mechanisms and the inadequacy of engineers [2]. In our country, masonry structures constitute a significant part of buildings. Mostly masonry structures emerge in rural areas, in urban areas after 1980s and in central settlements that are growing as a result of migration. Most of these structures are non-compliant with earthquake standards, have not received any engineering services, furthermore these structures are vulnerable to earthquake impacts and people dwelling in them face possible loss of property and lives [3]. In order to design structures that are resistant to earthquakes, the forces that are formed during the earthquake must be known and the behaviour of the structures under these forces must be well examined [4-5]. The earthquake regulation codes of 2007, is almost identical to that of 1997, with the exception of small-scale changes and an annexed section. This shows that new technologies do not reflect studies in the field of earthquake engineering. In the light of current needs, TBDY- 2007 was largely reserved and TBDY- 2018 was realized. To know the structural behaviour of a structure; it is very important to understand the consequences of existing earthquake damages under existing loads. Certain steps to be followed in determining these structural behaviours are;

- First, information about the structure to be examined should be collected. The historical development process of the building should be investigated and the effects that the building may be exposed to should be determined by evaluating the data obtained.

18 | P a g e

www.iiste.org 
- The second stage should be a detailed survey study for numerical modelling and structural analysis of the structure. These surveys should include material qualities as well as architectural details.

- Third, the values of the loads and environmental influences on the structure being examined must be calculated exactly, so that the analysis values are correct.

- The fourth stage, the interaction of the superstructure system elements, load transfer should be examined carefully.

- In the fifth stage, the modelling of the structure should be determined according to the data obtained in previous stages. According to the obtained datas, load condition of the structure and environmental effects should be calculated. Thus, the analysis of the structure can be easily obtained [6].

In this study, it is aimed to compare the earthquake performance analysis of a masonry structure made with Bayburt stone according to Old (TBDY-2007) and New (TBDY-2018). For this purpose, a technical Vocational High School for Girls building located in the city centre of Bayburt was handled and the survey work was carried out. After moving the measurement to AutoCAD program, the modelling was done with the help of StatiCAD-Masonry Program and performance analyses were obtained and results were compared.

\subsection{Bayburt Vocational High School For Girls Building}

According to local elders the building registered as parcel 9 of Tuzcuzade 481 Quarter in Bayburt province was built between 1941-1942 as a state enterprise for the purpose of accommodating passengers of road transport and served till 1960s as a hotel under the name of transit hotel. Over the years it was used as an educational facility under different names, more recently it was used as an educational building under the name of Çoruh Vocational and Technical Anatolian High School up to September 2017 when the building was evacuated as students moved to the new educational building which was Afterwards named as Girls' Vocational High School [7]. The Vocational School for Girls is located on Cumhuriyet Street, which is still the main street of Bayburt Province today as it was when it was built. Yellow Bayburt stones were used for the exterior cladding of the building and the top cover is covered with a roof. , The corridors extend from the main entrance of the two-storey building and rooms are lined up both on sides (right and left) of the corridors. The upper floor was applied as a repetition of the lower floor and the rooms were arranged on the corridors leading to both directions. The rooms are generally small in size and have been made into sections over time due to their function. Throughout the history of the building repair works have been made in the interior of the building from time to time. In the middle of the building there is an inner courtyard and it is thought that its purpose is to illuminate the interior.

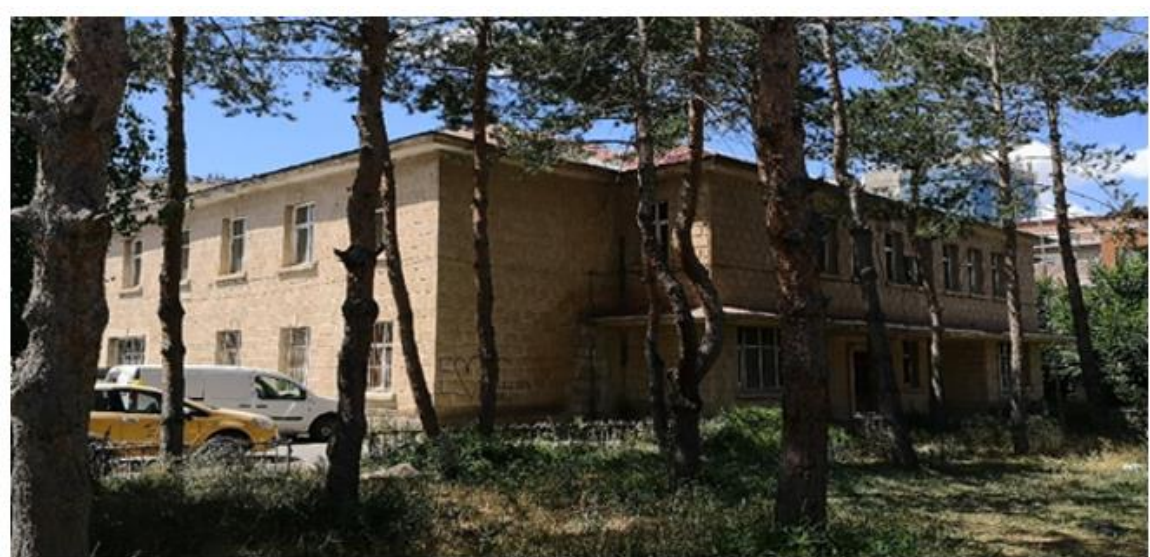

Figure 1. Left View of the Girl's Vocational High School Building (2019)

\section{Material and Method}

\subsection{Materials and Properties}

Previously performed studies have determined that natural stones have lower compressive and tensile strengths, It is also stated that the strength, durability and other material properties of masonry structural elements depend on the stone, mortar, and the texture of the stone depend to the way of its processing. In 
general, when it is not possible to determine the properties of the materials used in ancient masonry constructions, the properties of these materials can be obtained from past studies or from the 2007/2018 Earthquake Code Regulation for strength and physical properties of materials [6-8-9]. The average physical and mechanical properties of natural building stones were used in masonry structures. The values used in the analysis calculations for the stone wall were $450 \mathrm{~N} / \mathrm{mm}^{2}$ for Elasticity Modulus, 24 $\mathrm{kN} / \mathrm{m}$ Specific Gravity ${ }^{3}$ and 0.2 Poisson Ratio [10-11].

\subsection{Modelling of Bayburt Girls'Vocational High School Building}

For the modelling process of Girls' Vocational High School building, firstly, a survey work was performed. Although the first purpose of the building was to rest and accommodate passengers, the quality of the building did not lead to any change in the façade, although, small restoration works were observed. Survey Examples of Girls Vocational High School Building are given in Figure 2.
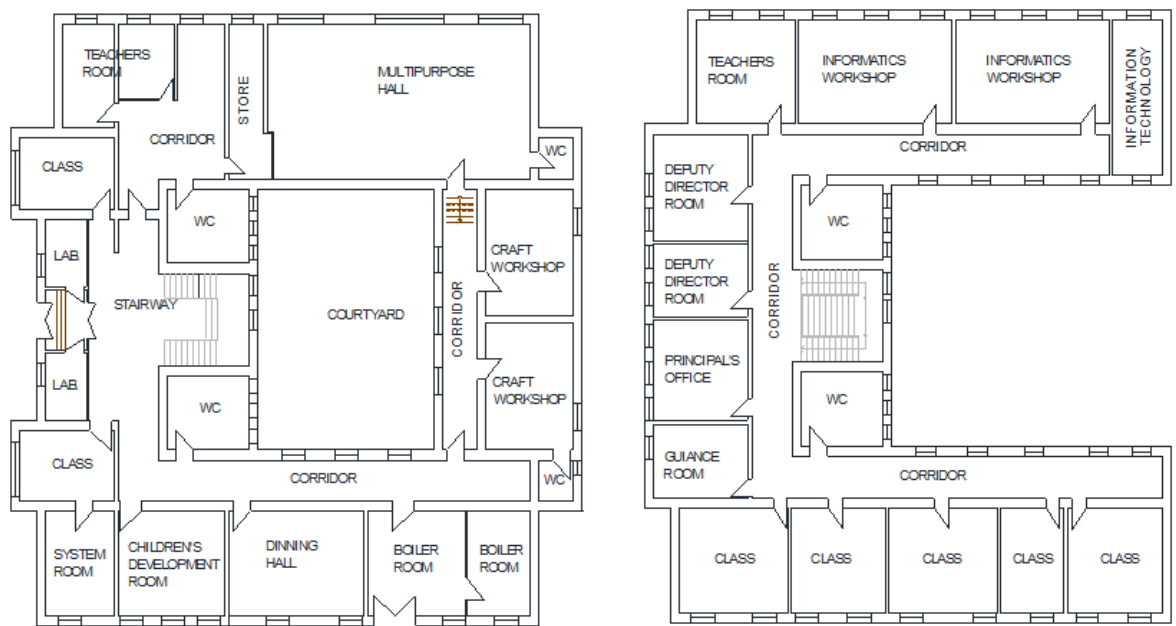

Figure 2. Survey Examples of Girls Vocational High School Building

StatiCAD-Yığma Program, was used to model the historical structure in accordance with the existing dimensions, due to its performance analysis ability. The three-dimensional view of the Girls Vocational High School Building is given in Figure 3.

The ground (soil) values subject to our study were determined by examining the ground survey reports of the recently constructed buildings in the vicinity. As the ground survey report values examined were close to each other, the ground survey report of the building closest to the Girls Vocational High School building was taken as reference. While dimensioning, the most suitable material for the actual material was worked on. The floor of the building is reinforced concrete. The beams in the structure were modelled according to their actual dimensions. Concrete class C16 and reinforcement class S220 were selected. Some of the walls on the ground floor are built with vertical perforated bricks while some of the walls on the first floor are built with blended bricks. The mechanical properties of the ground and the structural system are given in Table 1 and Table 2.

Table 1. Required Values Transferred to the StatiCAD-Masonry Program $[12,13,14]$.

\begin{tabular}{lc}
\hline Ground properties & values \\
\hline Ground Group & $\mathrm{D}$ \\
$\sigma_{\text {ground }}\left(\right.$ Ground Safety Tension $\left.\mathrm{t} / \mathrm{m}^{2}\right)$ & 18 \\
Local Ground Class & $\mathrm{ZC}$ \\
Spectrum Characteristic & $\mathrm{TA}=0.07(\mathrm{~s}) \mathrm{TB}=0.35(\mathrm{~s})$ \\
Ao (Effective Ground Acceleration Coefficient) & 0.2 \\
R (Carrier System Behavior Coefficient) & 2.5 \\
$\mathrm{~S}$ (T) (Spectrum Coefficient) & 2.5 \\
\hline
\end{tabular}


Table 2. Load Combinations Transferred to the StatiCAD-Masonry Program [13,14].

\begin{tabular}{lccc}
\hline Load Combinations & G & Q & E \\
\hline Load Combination for Pressure Stress & 1.0 & 1.0 & - \\
$\begin{array}{l}\text { Load Combination Used for slab } \\
\text { Reinforced Concrete Calculation }\end{array}$ & 1.4 & 1.6 & - \\
$\begin{array}{l}\text { Load Combination Used for Shear } \\
\text { Stress Calculation }\end{array}$ & 1.0 & HYKK & 1.0 \\
\hline $\begin{array}{l}\text { G: Dead Load Coefficient; Q: Live Load Coefficient; E: Seismic Load Coefficient; HYKK: Live Load } \\
\text { Participation Coefficient }\end{array}$ & &
\end{tabular}

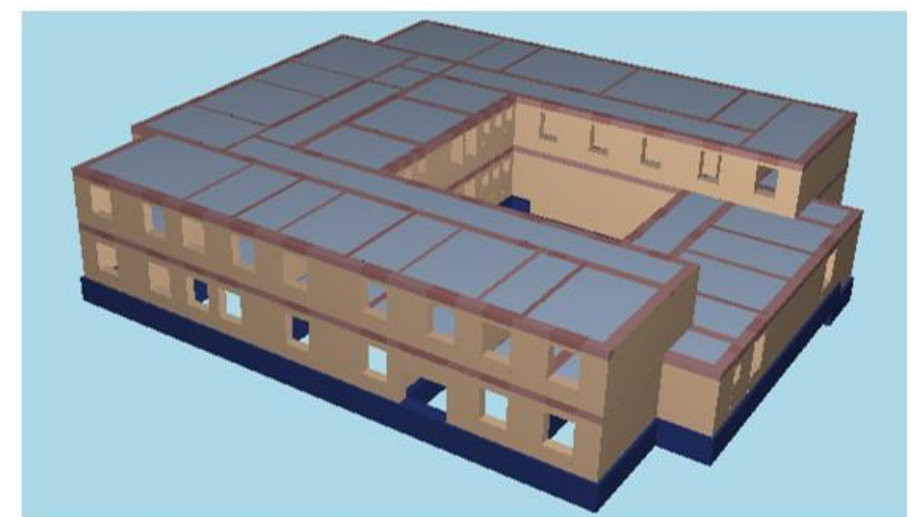

Figure 3. Three Dimensional View of Girls Vocational High School Building

When the analysis stage is reached in StatiCAD program, some of the parameters to be entered are the same while some of them differ. Calculations for earthquakes with a $10 \%$ occurrance probability in 50 years were selected for two regulations. By entering the parameters of building level coefficient 0,75 with limited level of knowledge, 2018 Earthquake Code, minimum information level and building level coefficient of 0.9 parameter were entered and the following results were obtained by analysing 2007 Earthquake Regulation;

- According to the 2007 Earthquake Regulation, it was determined that the Girls' Vocational High School building was 'Risk-Free'.

- According to the 2018 Earthquake Regulation, it is determined that the Girls' Vocational High School building is in a state of Immigration.

- Table 3 and Table 4 summarize the analysis of the regulations separately.

For both regulations, elements that do not yield enough pressure and shear stresses are shown in Figure 4 and Figure 5.

Table 3. StatiCAD-Masonry Program analysis results (1)

\begin{tabular}{|c|c|c|c|c|c|c|}
\hline \multicolumn{7}{|c|}{ TBDY-2007 EARTHQUAKE PERFORMANCE REPORT } \\
\hline Floor & Earthquake & Qi & $\mathrm{e}$ & Mbi & $\Sigma \mathrm{Wa}$ & $\Sigma \mathrm{Wn}$ \\
\hline Name & Direction & $(\mathrm{kN})$ & (m) & $(\mathrm{kNm})$ & $\left(\mathrm{m}^{2}\right)$ & (piece) \\
\hline Ground & $\mathrm{X}-\mathrm{X}$ & 5498.2 & 2.17 & 8121.7 & 71.36 & 46 \\
\hline Floor & Y-Y & 5498.2 & 1.480 & 11926 & 46 & 55 \\
\hline & $\mathrm{X}-\mathrm{X}$ & 3318.5 & -0.32 & 877.7 & 50 & 50 \\
\hline Ist Floor & Y-Y & 3318.5 & 0.26 & -1048.1 & 38.5 & 35 \\
\hline \multicolumn{7}{|c|}{ TBDY-2018 EARTHQUAKE PERFORMANCE REPORT } \\
\hline Floor & Earthquake & Qi & $\mathrm{e}$ & Mbi & $\Sigma \mathrm{Wa}$ & $\Sigma W n$ \\
\hline Name & Direction & $(\mathrm{kN})$ & (m) & $(\mathrm{kNm})$ & $\left(\mathrm{m}^{2}\right)$ & (piece) \\
\hline Ground & $\mathrm{X}-\mathrm{X}$ & 7916.2 & 3.06 & 10458.7 & 71.36 & 46 \\
\hline Floor & Y-Y & 7916.2 & 2.06 & 24228.2 & 58.5 & 55 \\
\hline \multirow{2}{*}{ 1st Floor } & $X-X$ & 4777.9 & 1.04 & 13191.9 & 66.47 & 50 \\
\hline & $Y-Y$ & 4777.9 & 0.15 & 7277.1 & 38.5 & 35 \\
\hline
\end{tabular}

Qi:Total shear force to the floors; e: Distance between floor mass centre and stiffness centre, Mbi:Floor Torsion Moment, $\mathbf{\Sigma W a}$ :Total wall area on the floor; $\boldsymbol{\Sigma} \mathbf{W n}$ :Total number of walls on the floor. 
Table 4. Load Combinations Transferred to the StatiCAD-Masonry Program [12]

\begin{tabular}{|c|c|c|c|c|c|c|}
\hline \multicolumn{7}{|c|}{ TBDY-2007 EARTHQUAKE PERFORMANCE REPORT } \\
\hline $\begin{array}{l}\text { Floor } \\
\text { Name }\end{array}$ & $\begin{array}{l}\text { Earthquake } \\
\text { Direction }\end{array}$ & $\begin{array}{l}\Sigma I W n \\
\text { (piece) }\end{array}$ & $\Sigma \mathrm{WL}(\mathrm{m})$ & $\begin{array}{l}\sum \mathrm{IVr} \\
(\mathrm{kN})\end{array}$ & $\begin{array}{l}\sum \mathrm{IVe} \\
(\mathrm{kN})\end{array}$ & $\begin{array}{c}\mathrm{IVe} / \mathrm{Qi} \\
(\%)\end{array}$ \\
\hline Ground & $\mathrm{X}-\mathrm{X}$ & 0 & 151.64 & - & - & - \\
\hline Floor & Y-Y & 2 & 155.23 & 362.7 & 453.6 & 8.2 \\
\hline & $\mathrm{X}-\mathrm{X}$ & 0 & 143.61 & - & - & - \\
\hline 1st Floor & $\mathrm{Y}-\mathrm{Y}$ & 3 & 108.25 & 347.6 & 406.1 & 12.2 \\
\hline \multicolumn{7}{|c|}{ TBDY-2018 EARTHQUAKE PERFORMANCE REPORT } \\
\hline $\begin{array}{l}\text { Floor } \\
\text { Name }\end{array}$ & $\begin{array}{l}\text { Earthquake } \\
\text { Direction }\end{array}$ & $\begin{array}{c}\Sigma I W n \\
\text { (piece) }\end{array}$ & $\begin{array}{c}\Sigma W L \\
(\mathrm{~m})\end{array}$ & $\Sigma \mathrm{IVr}(\mathrm{kN})$ & $\begin{array}{l}\Sigma \mathrm{IVe} \\
(\mathrm{kN})\end{array}$ & $\begin{array}{c}\mathrm{IVe} / \mathrm{Qi} \\
(\%)\end{array}$ \\
\hline Ground & $\mathrm{X}-\mathrm{X}$ & 36 & 151.64 & 14655 & 7870.7 & 99.4 \\
\hline Floor & $Y-Y$ & 36 & 155.23 & 9371.5 & 7706.6 & 97.4 \\
\hline 1st Floor & $X-X$ & 41 & 143.61 & 11852.1 & 4680 & 98 \\
\hline 1st Floor & Y-Y & 9 & 108.25 & 4355.2 & 4391.5 & 91.9 \\
\hline
\end{tabular}

$\boldsymbol{\Sigma I W n : T o t a l ~ n u m b e r ~ o f ~ i n s u f f i c i e n t ~ w a l l s ~ o n ~ t h e ~ f l o o r ; ~} \boldsymbol{\Sigma I W a}$ :Total insufficient wall area on the floor; $\boldsymbol{\Sigma} \mathbf{W L}$ :Total wall length on the floor; $\boldsymbol{\Sigma} \mathbf{I V r}$ :Total of walls with insufficient shear capacity; $\boldsymbol{\Sigma} \mathbf{I V e}:$ Total of shear force to walls with insufficient capacity; $\sum \mathbf{I V e} / \mathbf{Q}$ i: Contribution of insufficient strength walls to floor shear force.

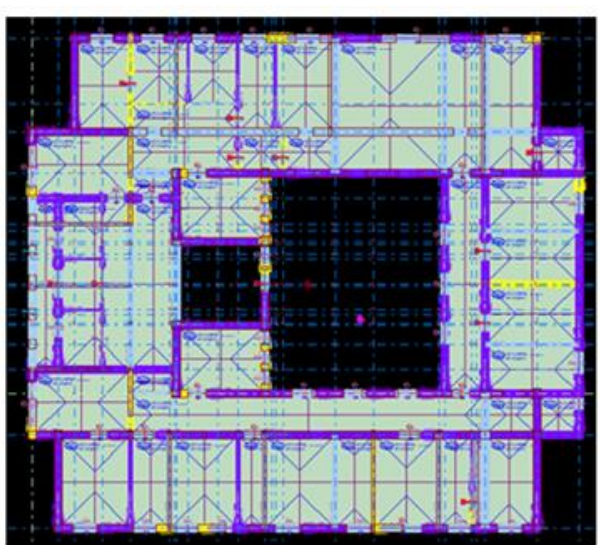

TBDY-2018

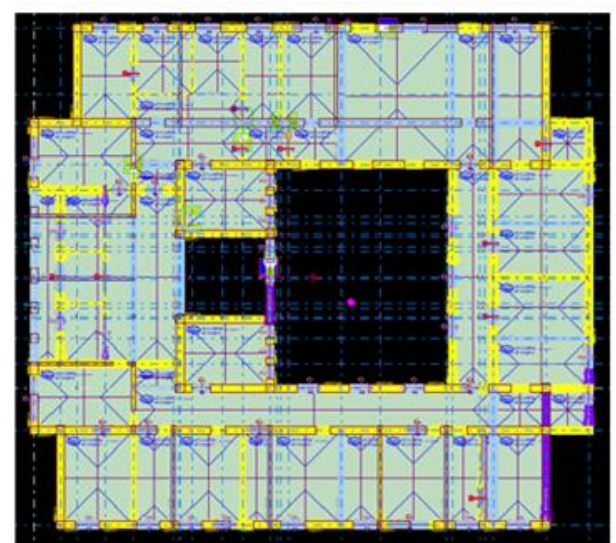

TBDY-2007

Figure 4. Elements that do not yield pressure and shear stresses on the ground floor as a result of the analysis

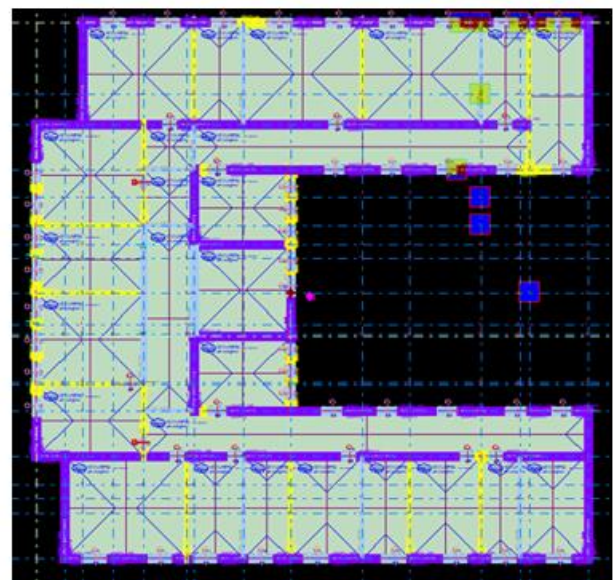

TBDY-2018

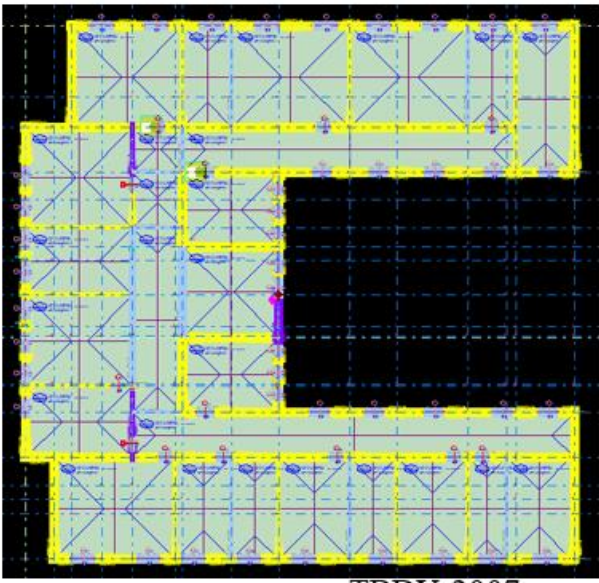

TBDY-2007

Figure 5. Elements that do not yield pressure and shear stresses on the first floor after analysis

\section{Results and discussion}

In this study, we have worked on obtaining the performance of the Girls' Vocational High School building constructed by using Bayburt stone against the expected earthquakes in 50 years with $10 \%$ occurrance probability. The results of the analysis made with the help of StatiCAD Masonry Package Program were

22 | P a g e

www.iiste.org 
evaluated according to the old and new earthquake regulations. As it is in the case of masonry structures, mechanical properties of the building material were determined by taking as reference similar studies in the literature.

- As a result of the analysis of the structure, according to TBDY- 2007, 46 walls were found sufficient in the $\mathrm{X}-\mathrm{X}$ direction and 6 out of 55 walls in the $\mathrm{Y}-\mathrm{Y}$ direction were found insufficient. On the 1st floor, all 50 walls in X-X direction were found sufficient and in Y-Y direction, 4 out of 35 walls were found to be insufficient. According to TBDY- 2018, 36 of the 46 walls in the $\mathrm{X}-\mathrm{X}$ direction were found insufficient in the ground floor, 36 of the 55 walls in the $\mathrm{Y}-\mathrm{Y}$ direction were found insufficient.

- In the first floor, 41 out of 50 walls in the X-X direction were found insufficient, and 9 out of 35 walls in the Y-Y direction were found insufficient. While $6 \%$ of the 101 walls on the ground floor of the building were found insufficient compared to TBDY- 2007, this value corresponds to approximately $72 \%$ compared to TBDY -2018 .

- While $85 \%$ of the 85 walls on the first floor of the building are insufficient compared to TBDY2007 , this value corresponds to approximately $60 \%$ compared to TBDY -2018.

- While the earthquake force acting on the ground and first floor of the building was 560.66 338.39 (ton) according to TBDY- 2007, this value was found to be 807.23 - 487.21 (ton) according to TBDY- 2018.

- When the effect of the insufficient walls on the ground and first floor of the building on the shear force was examined, it was observed that the values were below $13 \%$ according to TBDY2007, whereas this value was above $91 \%$ according to TBDY - 2018.

- The deficiencies in the walls are shown in different colors in Figure 4 and Figure 5. In the walls indicated with orange color, no pressure stress is provided. Shear stress was not provided on the walls indicated with purple color. Both the pressure and shear stress were not provided on the walls indicated with red color.

- When the walls of the building are examined, it is seen that they have been subjected to repairs in time. Of course, this situation brings some problems and lack of information in the stages of data acquisition. In the present study, due to the fact that the actual mechanical properties of Bayburt natural stone and other materials used are not known, the results of the analysis are handled with a rough approach.

- In the analyzes, the importance of the hazard arising from the earthquake was further emphasized in the new regulation.

- In general, it is seen that the values determined in the new earthquake regulations are higher.

\section{Conclusions}

The analyzes applied at the Girls' Vocational High School building were performed according to TBDY2007 and TBDY- 2018 with the help of StatiCAD Masonry program for modeling.

When the results of pressure and shear stresses in the structure are examined; According to TBDY- 2007, it has been observed that the safety stresses taken in the literature are above the values and although the structure is considered as a risk-free building, when the available data are examined according to TBDY2018 , it is observed that the safety stresses taken in the literature are below the values and this situation indicates that there may be a collapse of the structure. Therefore, the structure is considered to be insecure. Due to the fact that the structure is a cultural heritage, it is thought that the reinforcement should be made in the superstructural elements while keeping the building true to its original materials used in the structure, thus preventing the collapse.

\section{Acknowledgements:}

In this study, my doctoral student Selçuk ÇİMEN, graduate students Elif YILMAZ and Baraka CIZZA contributed.

\section{References}

[1] Chamber of Mechanical Engineers (TMMOB) (2010), "The fact of earthquake in Turkey and Chamber Of Mechanical Engineers' suggestions" [Online] Available: https://www.google.com/url? sa=t\&rct=j\&q=\&esrc=s\&source=web\&cd=1\&ved=2ahUKEwia1v W3n5TlAhWjlYsKHelqBLYQFjAAegQIAhAC\&url=http\%3A\%2F\%2Fwww1.mmo.org.tr\%2F resimler\%2Fdosya_ekler\%2Fee9b8f616afde72_ek.pdf\&usg=AOvVaw0n13jtHQUJ8yE4La14Sh

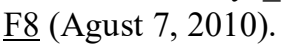

23 | P a g e 
[2] Kibici, Y.,(2005), “Eartquake”, Afyon Kocatepe University Earthquake Application and Research Center, Publication Id: 59, Afyonkarahisar.

[3] Simşek, C..,(2005), "Masonry Structures in Rural Areas and Social and Institutional Factors in Providing Earthquake Safety", Workshop on Improving Earthquake Safety of Masonry Structures (YDGA2005), 2005, Ankara.

[4] Çıl1, F., (1978), "Calculation of masonry structures according to horizontal loads" Earthquake Research Institute Bulletin, 22, 7-25.

[5] Bayülke, N.,(1978), "Behavior of brick masonry structures in earthquakes" Earthquake Research Institute Bulletin, 22, 26-42.

[6] Can, H. ve Ünay., A.,İ.,(2012), "Numerical Analysis Tools to Determine Earthquake Behavior of Historical Structures", Journal of the Faculty of Engineering and Architecture of Gazi University, 27(1), 211-217.

[7] Republic of Turkey Ministry of National Education, Bayburt-Çoruh Vocational and Technical Anatolian High School, (2019), "Short history," 2019. [Online]. Available: http://coruhmtal.meb.k12.tr/meb_iys_dosyalar/69/01/152675/icerikler/okulumuzuntarihcesi 5852.html?CHK=93892f8589d2559b6225173bc0e1cdf9 (July 17, 2019)

[8] Çobanoğlu, A.B.,(2014), "Investigation of Material Properties for The Turkish Masonry Buildings", Master Thesis, The Graduate School of Natural and Applied Sciences of Middle East Technical University, Ankara.

[9] Aslan, A., (2016), "Evaluation of Suleymaniye Mosque's earthquake performance due to local soil conditions”, Doctoral Thesis, Yildiz Technical University, İstanbul.

[10] Ünay, A., (2002), "Earthquake Resistance of Historical Buildings", METU Faculty of Architecture, Ankara.

[11] Durutürk, G., (2012), "Earthquake analysis of Yalvaç Hamidiye Mosque”, Süleyman Demirel University Graduate School of Natural and Applied Sciences, Isparta.

[12] Disaster and Emergency Management Presidency (AFAD), (2007), "Turkey earthquake regulations (TDY-2007)", Ankara.

[13] Disaster and Emergency Management Presidency (AFAD), (2018), "Turkey earthquake regulations (TDY-2018)", Ankara.

[14] TS 500, (2000), "Requirements for Design And Construction of Reinforced Concrete Structures", Turkish Standard Institute, Ankara. 